\title{
O POGRANICZU SŁOWOTWÓRCZO-LEKSYKALNYM WERBALNYCH STRUKTUR WIELOZNACZNYCH W GWARACH POLSKICH
}

\author{
Izabela Ejsmunt-Wieczorek \\ Uniwersytet Łódzki \\ ORCID: 0000-0002-1802-0005
}

\begin{abstract}
Streszczenie. Jest to kolejny z cyklu artykuł, poświęcony zjawisku polisemii werbalnej w gwarach polskich. Wychodząc od zagadnienia pogranicza słowotwórczo-leksykalnego, w artykule podjęto problem funkcji kategorialnych formantów tworzących konstrukcje czasownikowe tożsame formalnie, które m.in. w wyniku przesunięć znaczeniowych, implikują dublety oraz ciągi polisemantyczne. Problem zilustrowano na przykładach pochodzących z eksploracji terenowej pogranicza małopolsko-mazowieckiego oraz z dostępnych źródeł publikowanych, zawierających dokumentację dialektalną.
\end{abstract}

Słowa klucze: gwara, słowotwórstwo, semantyka, pogranicze, czasownik, polisemia, kategoria słowotwórcza

W języku polskim słowo pogranicze ma ponad 30 synonimów. Zwykle rozumiane jest jako: „obszar w pobliżu granicy dzielącej pewne przestrzenie”, „okres, stan lub obszar, w którym graniczą ze sobą dwie kultury, epoki”, "styk zbliżonych dziedzin" itp. ${ }^{1}$ Sławomir Gala, powołując się na teorię kontaktu Uriela Weinreicha, opisuje pogranicze interpersonalne, środowiskowo-lokalne oraz historyczno-geograficzne ${ }^{2}$. Według Bogdana Walczaka „na pograniczach [...] zawsze rodzą się wartości wyjątkowe i oryginalne”, co może zaowocować nową jakością ${ }^{3}$. Z definicji tych wynika, że wyznacznikami pogranicza są: złożoność, wzajemne przenikanie się i pewnego rodzaju współzależność. Powyższy artykuł dotyczy dość specyficznie rozumianego pogranicza, gdyż łączy w sobie dwa trudne i dyskusyjne zagadnienia, pozostające ze sobą w ścisłej relacji. Z jednej strony odnosi się do zjawiska polisemii, które

SWJP, 2001, s. 83.

S. Gala, Z metodyki badań pogranicza językowego (na materiale polskim), [w:] Język i kultura na pograniczu polsko-ukraińsko-białoruskim, red. F. Czyżewski, Lublin 2001, s. 29.

3 B. Walczak, Bug nie musi dzielić, [w:] Język i kultura na pograniczu polsko-ukraińsko-białoruskim, red. F. Czyżewski, Lublin 2001, s. 19. 
nieustająco wywołuje wiele kontrowersji i prowadzi do zagorzałych polemik wśród językoznawców na całym świecie ${ }^{4}$. $Z$ drugiej zaś strony podejmuje kwestię semantycznej kategoryzacji derywatów, stanowiącej jeden z najtrudniejszych elementów opisów słowotwórczych, zarówno na gruncie języka ogólnego, jak również na płaszczyźnie historycznej i gwarowej ${ }^{5}$. O właściwości współczesnego słowotwórstwa, silnie powiązanego z poziomem leksykalnym języka, oraz o wpływie semantyki leksykalnej na znaczenie kategorialne derywatu pisali m.in.: Maria Honowska, Mirosław Skarżyński czy Irena Ja$\operatorname{ros}^{6}$. Także Aleksandra Janowska, odwołując się do werbalnych derywatów staropolskich, podkreślała zależność zachodzącą pomiędzy rozbudowaną polisemią czasownika a opisem kategorialnym, zauważając, że konsekwencją niektórych procesów leksykalnych, w tym wieloznaczności, jest zacieranie wyrazistości przedrostków, zwiększanie ich wielofunkcyjności, a co się z tym wiąże, brak przejrzystych kategorii znaczeniowych ${ }^{7}$. Mając na uwadze konkluzję A. Janowskiej, w artykule podjęto próbę ustalenia głównych funkcji kategorialnych formantów tworzących wieloznaczne struktury czasownikowe tożsame formalnie, opierając się na materiale gwarowym pochodzącym z eksploracji autorskiej pogranicza małopolsko-mazowieckiego oraz z dostępnych źródeł publikowanych, zawierających dokumentację dialektalną.

W języku mamy do czynienia $\mathrm{z}$ dwoma zjawiskami, które często utożsamia się ze sobą: niejednoznacznością i wieloznacznością. Zdaniem Katarzyny Wojan „,niejednoznaczność zakorzeniona jest w chaosie”, bo ,język jest bezwolnym przedmiotem w procesie komunikowania międzyludzkiego,

4 Na temat zjawisk: polisemii, homonimii i swoistego pogranicza między nimi (sfera zjawisk przejściowych) wypowiadała się K. Wojan, Wstęp do badań wieloznaczności leksemów w ujęciu kontrastywnym, Gdańsk 2010, s. 11.

O trudnościach interpretacyjnych wyrazów podzielnych słowotwórczo piszą zarówno badacze polszczyzny ogólnej (np. J. Puzynina 1962, s. 34; EJP 1999, s. 179), historycznej (np. A. Janowska, M. Pastuchowa 2005, s. 13), jak i gwarowej (S. Gala, B. Gala 2006; J. Sierociuk 2007; T. Kurdyła 2012; I. Ejsmunt-Wieczorek 2012).

6 Por. M. Honowska, Ewolucja metod polskiego stowotwórstwa synchronicznego (w dziesięcioleciu 1967-1977), Wrocław, 1979, s. 4; M. Skarżyński, Powstanie i rozwój polskiego stowotwórstwa opisowego, Kraków 1999, s. 73 czy I. Jaros, Nazwy środków czynności w gwarach tęczycko-sieradzkich. Studium stowotwórczo-leksykalne, Łódź 2009, s. 34.

7 Problem pogranicza słowotwórczo-leksykalnego i związków zachodzących pomiędzy derywacją i semantyką nie jest w językoznawstwie obcy. M.in. A. Janowska, nawiązując do teorii J. Apresjana, podkreśla, że ,zarówno słowotwórstwo, jak i leksyka biorą udział w takim samym zakresie w aktach nominacji” i są „równouprawnionymi środkami językowymi, wykorzystywanymi w języku w zależności od potrzeb”. Dzięki temu pograniczu możemy poznać nowe znaczenia czasowników i proces kształtowania się kategorii słowotwórczych, por. A. Janowska, Polisemia staropolskich czasowników. Źródła, swoistość, konsekwencje, Katowice 2007b, s. 8-9; eadem, Polisemia jako czynnik przemian w polskich czasownikach prefiksalnych, [w:] Stowotwórstwo stowiańskie: system i tekst, red. J. Sierociuk, Poznań 2012, s. 207-208. 
a o precyzji przekazu intencji intelektualnej decyduje tylko człowiek"8. Zatem niejednoznaczność może prowadzić do zamętu komunikacyjnego i ogólnego niezrozumienia wśród odbiorców, jeśli nadawca wypowiedzi nie wyrazi swoich myśli w precyzyjny sposób. Natomiast wieloznaczność, którą język kreuje sam, oparta jest na systematyce, to człowiek musi się jej podporządkować i dostosować. Systematyka kojarzy się zwykle z czymś uporządkowanym i konsekwentnym, dlaczego zatem problem wieloznaczności uważa się za jeden z najtrudniejszych we współczesnej semantyce i do dziś nie ma jasno określonych wzorców terminologicznych oraz metodologicznych? ${ }^{9}$ Zapewne wiąże się to ze strukturalistycznym podziałem języka na płaszczyznę langue (abstrakcyjną i społeczną) oraz parole (konkretną i jednostkową). Język jest stały, a mowa zmienna. Dlatego też badanie polisemii w gwarach (w mowie ludności wiejskiej) stanowi nie lada wyzwanie. Błażej Osowski, omawiając wariantywność leksykalno-znaczeniową języka wielkopolskich inwentarzy, pisał, że ,w gwarach ludowych obserwuje się większą dowolność w zakresie słowotwórstwa i słownictwa [...], a synonimia służy uściślaniu informacji”'10. Za Adamem Heinzem rozumie on synonimię jako zwielokrotnienie formy przy zachowaniu tej samej funkcji. Poszczególne warianty, jako jednostki mówienia (parole), konkurują ze sobą o zajęcie tego samego miejsca w systemie językowym. W przypadku polisemii jest odwrotnie, ponieważ mamy do czynienia ze zwielokrotnieniem funkcji, przy zachowaniu tej samej formy wyrazowej, a powstające jednostki słowotwórczo-semantyczne na płaszczyźnie parole wprowadzają raczej chaos znaczeniowy.

Samo pojęcie polisemii (z grec. Polysemos, czyli poli + sema ,znak') po raz pierwszy zostało użyte $\mathrm{w}$ językoznawstwie pod koniec XIX wieku przez francuskiego filozofa Michaela Bréala, który zgłębiał tajniki znaczenia wyrazów.

Od tamtej pory jest ono różnie definiowane, np. jako wielofunkcyjność tego samego kształtu językowego ${ }^{11}$, wielopłaszczyznowe zjawisko, które zwykle sytuuje się gdzieś na pograniczu poznania, dyskursu, jego zasad oraz specyficznej leksykalizacji ${ }^{12}$, pomost łączący przeciwstawne bieguny: mono-

\footnotetext{
$8 \quad$ K. Wojan, op. cit., s. 17.

9 Ibidem, s. 85; A. Raszewska-Klimas, Wieloznaczność nazwisk Polaków, Łódź 2018, s. 17.

10 B. Osowski, Wariantywność leksykalno-semantyczna języka wielkopolskich inwentarzy z drugiej połowy XVIII wieku. Studia z dialektologii historycznej, Poznań 2019, s. 57, 63.

11 A. Raszewska-Klimas, op. cit., s. 16.

12 Polysemy is a complex multi-level phenomenon right at the crossroads where cognition, discourse, discourse rules and idiosyncratic lexicalization meet, cytat $\mathrm{z}$ : A. Blank, Polysemy in the lexicon and in discourse, [w:] Polysemy. Flexible patterns of Meaning in Mind and Language, red. B. Nerlich, Z. Todd, V. Herman, D.D. Clarke, M. de Gruyter, Berlin-New York 2003, s. 267.
} 
semię i homonimię ${ }^{13}$. Na ogół do badań nad wieloznacznością podchodzi się $\mathrm{z}$ dużą rezerwą, uważając to zjawisko za: rodzaj nieładu językowego, zagrożenie zaburzające wyuczone schematy zachowań językowych, objaw ubóstwa języków, źródło błędów językowych, przejaw niewydolności funkcji segregacyjnej języka, marginalny rezultat pracy klasyfikacyjnej nad językiem, przejściowe stadium języka, świadectwo niedoskonałości i przypadkowości mowy oraz balast utrudniający komunikację ${ }^{14}$. Jednocześnie zauważa się, że rozbudowana polisemia może świadczyć o dużej elastyczności języka, o jego możliwościach kreatywnych oraz o znacznym potencjale leksykalnym, prowadzącym do powoływania twórczych przesunięć ${ }^{15}$. W języku ogólnym czy też w polszczyźnie historycznej możemy przytoczyć liczne czasowniki wieloznaczne, świadczące o istnieniu polisemii werbalnej, np.: bić 1. 'uderzać', 2. 'pulsować (o sercu)', 3. 'wydawać dźwięk gongu' ${ }^{16}$ lub staropolskie odkazać 1.'nakazać, polecić': Eże Bochna odkazała Piotrkowi dać z swego posagu panu poznańskiemu trzynaście grzywny 1399 Pozn nr 365; 2. 'przekazać, zapisać': Tedy przedat ten winowaciec swój dom i odkazat te pieniadze, co byt dlużen OrtBr VI 367; 3. 'odmówić, pozbawić prawa do czegoś': Jako Męcimir nie miat brać tych pieniędzy, cso mu jednacze odkazali na Janie [...] 1446 ZapWarsz nr 760; 4. 'o poddanym chłopie - zawiadomić pana feudalnego o zamiarze odejścia z jego wsi': Jako się Jan przede mna nie odkazal 1436 ZapWarsz nr 680; 5. 'powiadomić': Kto mi odkaże, powieli cso ociec twój twardego tobie o mnie? BZ I Reg20, 10. 50 ${ }^{17}$. Natomiast w gwarach ${ }^{18}$ problem wydaje się znacznie bardziej złożony, ponieważ musimy wziąć także pod uwagę aspekt geografii lingwistycznej ${ }^{19}$. O rzeczywistej polisemii werbalnej możemy mówić, badając verba tylko w obrębie jednej gwary, np. czasownik nagnać w gwarze Turowej Woli na południowym Mazowszu ma dwa różne znaczenia: 1. 'popędzić co lub kogo do określonego miejsca' tymy kołatkamy nagnały mu dzika na cel, 2. 'sypnąć śniegiem' taka kurzawa sie robi, wjater tyle śniegu nagna, zaspy usypje $e^{20}$; podobnie derywat werbalny napchać sie w gwarze Domaniewka w powiecie łęczyckim oznacza: 1. 'zmęczyć się pcha-

\footnotetext{
13 L. Jochym-Kuliszkowa, Uwagi o homonimii i polisemii leksykalnej w formacjach stowotwórczych, [w:] Problemy semantyki leksykalnej, red. M. Blicharski, Katowice 1986, s. 7.

$14 \quad$ K. Wojan, op. cit.; A. Janowska, Polisemia staropolskich..., s. 7.

15 Ibidem, s. 10.

16 EJP, 1999, s. 288.

17 A. Janowska, Polisemia staropolskich..., s. 48.

18 Gwara jako odmiana języka narodowego (etnicznego), ukształtowana w wyniku ewolucji tegoż języka (por. I. Jaros, op. cit., s. 11).

19 Geografia językowa rozumiana w ujęciu dialektologicznym jako przestrzenne zróżnicowanie faktów językowych, wykrywanie językowych różnic terytorialnych na badanym terenie.

20 Przykłady pochodzą z gwary mieszkańców Turowej Woli na południowym Mazowszu (materiał własny) i w dalszej części tekstu będą oznaczane skrótem (TW).
} 
niem czegoś', 2. 'zjeść czego dużo' tymy prazuchamy to sie kożdy napcho, 3. 'wejść tłumnie, licznie' napchało sie tych kobit po te nafte jak nigdy ${ }^{21}$. Natomiast porównując znaczenia czasowników pochodzących z różnych gwar, często przynależnych do odrębnych dialektów, a więc stanowiących osobne systemy językowe, można jedynie mówić o tzw. odpowiednikach innogwarowych o charakterze wieloznacznym (inna proponowana nazwa: słowotwórczo-leksykalne zbieżności gwarowe lub quasi-polisemy). Za takie uznaje się wyrazy o różnej proweniencji geograficznej, jednakże tożsame pod względem budowy, tzn. utworzone od identycznej podstawy słowotwórczej, za pomocą takiego samego wykładnika derywacyjnego, ale posiadające odrębne znaczenia, np.: dobrać: brać 1. 'wziąć dodatkowo' zińć przyjechot, jeszcze jednygo do tych królików se dobrat (TW); 2. 'dopasować coś do czegoś' dobrot kunia na jarmarku podtuk sfojigo kaśtana 22; 3. 'dawać się we znaki, doskwierać' raz sie obróciół na jedne stróne - spad, znowa na drugo stróne, a zaś spad, tak moc razy spadowat, kiym mu nie dobrata zima ${ }^{23}$; nasztorcować: na sztorc 1. 'ustawić pionowo' naładowat betonu i naśtorcowat ściane do równości (TW); 2. 'płytko zorać' ${ }^{24} ; 3$. 'nakrzyczeć, złajać' o byle gówno naśtorcujom jak glupie $e^{25}$.

Przeświadczenie o potrzebie prowadzenia badań nad polisemią w danej gwarze i nad semantyczno-słowotwórczymi zbieżnościami gwarowymi wyrasta z przeglądu dość bogatej polskiej literatury współczesnej, np.: R. Grzegorczykowa (1966), E. Grodziński (1969; 1972), J. Wróblewski (1980), J. Tokarski (1981), L. Jochym-Kuliszkowa (1986), M. Majewska (2001; 2006), A. Czelakowska (2014), oraz historycznej, np.: W. Doroszewski (1949), D. Buttler (1968; 1991), M. Kucała (1994), M. Witkowska-Gutkowska (1999), A. Janowska (2006; 2007), i jakże skromnych opracowań gwarowych w postaci pojedynczych artykułów: H. Pelcowa (2003), S. Gala (2010), R. Marciniak-Firadza (2014), Ejsmunt-Wieczorek (2017). Przegląd powyższy pokazuje wyraźny deficyt tego typu badań i poświęconych im szkiców na gruncie gwarowym. Tę zauważalną lukę w opracowaniach dialektalnych Sławomir Gala thumaczył brakiem odpowiednich danych gwarowych, wynikającym z niewielkiego zaawansowania prac nad słowotwórstwem gwarowym oraz fragmentarycznością dokumentacji leksykograficznej ${ }^{26}$. Ponadto wymie-

21 M. Szymczak, Stownik gwary Domaniewka w powiecie tęczyckim, Wrocław-WarszawaKraków 1962-1973, t. 4, s. 616.

22 Ibidem, t. 1, s. 108.

23 J. Kąś, Stownik gwary orawskiej, Kraków2011, t. 1, s. 165.

24 B. Sychta, Stownictwo kociewskie na tle kultury ludowej, Wrocław-Warszawa-KrakówGdańsk 1980, 1985, t. 1, s.101.

25 M. Szymczak, op. cit., t. 6, s. 1001.

26 S. Gala, Glosa do zagadnienia homonimii/polisemii w stowotwórstwie gwarowym, „Rozprawy Komisji Językowej Łódzkiego Towarzystwa Naukowego”, 2010, t. LV, s. 85. 
nione nieliczne prace dialektalne w całości poświęcone są polisemii nominalnej. Czasownik w tego typu opracowaniach traktowany jest marginalnie, co może dziwić, zważywszy na fakt, iż niektórzy językoznawcy są przekonani, że to właśnie verba odznaczają się największym stopniem polisemiczności ${ }^{27}$ i stanowią przydatny materiał do opisu pogranicza słowotwórczo-leksykalnego. „Problemy związane z pograniczem leksykalno-słowotwórczym znajdują najpełniejsze odzwierciedlenie w derywacji czasownikowej, która [...] należy $\mathrm{z}$ tego właśnie powodu do najtrudniejszych $\mathrm{w}$ analizie"28. Pewnego rodzaju ostrożność $\mathrm{w}$ prowadzeniu badań czasowników w gwarach wiąże się zapewne z ich złożoną interpretacją znaczeniową, której konsekwencją są trudności w ustalaniu niuansów semantycznych badanych derywatów. Aleksandra Janowska sygnalizowała, że opisanie słowotwórstwa czasownikowego, w szczególności derywatów prefiksalnych, to dość skomplikowane zadanie, „niedające się łatwo ująć w karby klasyfikacji” ze względu na liczbę „możliwych kombinacji semantycznych wynikających ze splotu wielofunkcyjnych prefiksów i znaczeń podstaw werbalnych". Choć przynależność do kategorii słowotwórczej w znacznej mierze zależy od znaczenia leksykalnego derywatu, a granice kategorii są rozmyte i mogą w ich zakres wchodzić derywaty należące do innych kategorii, to zasadność i konieczność ujęcia kategorialnego, a zatem ustalenia poszczególnych funkcji przedrostków widzi wielu językoznawców ${ }^{29}$.

Ze zjawiskiem nieostrości granic kategorii słowotwórczych spotykamy się przy opisie derywatów różnych części mowy. Niektórzy językoznawcy uważają jednak, że to przede wszystkim czasownik jest tą częścią mowy, która nie wpisuje się w istniejące modele klasyfikacji słowotwórczej ze względu na brak regularności kategorialnej i ogromne rozdrobnienie znaczeniowe ${ }^{30}$. Inni z kolei są zdania, że to właśnie czasownik stanowi wdzięczny materiał do opisu pogranicza słowotwórczo-leksykalnego, bo tylko w taki sposób możemy zaobserwować kierunek rozwoju semantycznego wyrazu oraz proces kształtowania się kategorii słowotwórczych ${ }^{31}$.

Derywacja czasownikowa charakteryzuje się szerokim zasobem kategorii słowotwórczych, których wykładnikami są w głównej mierze formanty przedrostkowe. „To prefiksy decydują o rozwoju kategorii słowotwórczych, [...] są

\footnotetext{
27 Por. K. Wojan, op. cit., s. 90.

28 A. Janowska, O roli analogii w stowotwórstwie (na przykładzie czasowników staropolskich), „LingVaria” 2 (4), 2007a, s. 115.

29 A. Janowska, Polisemia jako czynnik..., s. 203; K. Kleszczowa, Na straży niezmienności modeli słowotwórczych, „Biuletyn Polskiego Towarzystwa Językoznawczego” 2007, t. LXIII, s. 116.

30 H. Wróbel, Czasownik, [w:] Gramatyka współczesnego języka polskiego. Morfologia, red. R. Grzegorczykowa, R. Laskowski, H. Wróbel, Warszawa 1998, s. 542-544.

31 Por. A. Janowska, Polisemia staropolskich..., s. 9.
} 
wyznacznikami zmian aspektowych, [...] stanowią podłoże zmian znaczeniowych w obrębie czasowników prostych" ${ }^{32}$. Przedrostki sprowadzają derywaty do „wspólnego mianownika semantycznego" ${ }^{33}$. Za najbardziej wyrazistą, prymarną wartość prefiksów werbalnych uznaje się znaczenie przestrzenne (lokatywne), w którym wyrazami motywującymi są najczęściej czasowniki ruchu $^{34}$, oznaczające przemieszczanie $\mathrm{w}$ przestrzeni. Znaczenia werbalnych struktur przestrzennych o charakterze wieloznacznym często mają charakter przeciwstawny, ponieważ wnoszą informacje wskazujące zarówno na oddalenie od danego obiektu (derywaty ablatywne), jak i na przybliżenie do obiektu (derywaty adlatywne), np. odleciéc, ujechać, ujść. Zjawisko enantiosemii ${ }^{35}$ było charakterystyczne dla formacji wieloznacznych w dobie staropolskiej i choć jego stopniowa eliminacja rozpoczęła się w XIX wieku, skłonność do tworzenia antonimicznych zbieżności międzysystemowych przetrwała do dziś w gwarach, np.: odlecieć 1. 'odejść na niewielką odległość' kawatek za brame todleći, ale dalej sama nie pójdzie (TW), 2. 'pokonać dużą odległość' cug już kawat odleciat, zjidzcie z nami wjeczerze ${ }^{36}$; uciagnąć 1. 'podnieść do góry - ruch w linii pionowej' przeważyt tygo żurawia w dót ji uciongnot to wjadro do góry (TW), 2. 'ciągnąc coś, przemieścić w ruchu poziomym' ten koń [...] nie mógt tego woza tuciongnońć, bo świeżo, to sie te koła w śniegu zarywały ${ }^{37}$; ujechać 1. 'pokonać dużą odległość' matka płacze, że taki kawat drogi musiała ujechać, żeby jakom prace znaleś (TW), 2. 'pokonać niewielką odległość' tujechot pore kroków ji stanut ${ }^{38}$; ino kawatek tujechot $i$ mu sie auto popsuto; tak sobje ino tujechatem ${ }^{39}$; ujść 1. 'przebyć pieszo znaczną odległość' tam uszet kawat, aż za rzundowy las (TW), 2. 'z trudem pokonać pieszo niewielką odległość' taki wiatr byl, że ni możno byto tujś ${ }^{40}$; nachlot sie wódki, że ni może tujś nawet ${ }^{41}$.

Kolejną zwartą i reprezentatywną grupę stanowią derywaty rezultatywne, związane z funkcją czasową, oznaczające osiągnięcie granicy końcowej,

32 Ibidem, s. 55.

33 W. Śmiech, Derywacja prefiksalna czasowników polskich, Wrocław-Warszawa-KrakówGdańsk-Łódź 1986, s. 7.

34 Czasowniki ruchu posiadają wspólną cechę morfologiczną, czyli podwójne tematy bezprefiksalne o aspekcie niedokonanym, np.: biec-biegać, iść - chodzić, jechać-jeździć, nieść - nosić.

35 Katarzyna Wojan przy tego typu przeciwieństwach znaczeniowych mówi o zjawisku polaryzacji znaczeń bądź o antonimach polisemicznych (por. K. Wojan, op. cit., s. 127).

36 H. Górnowicz, Dialekt malborski, Gdańsk 1967, 1973-1974, t. 2, s. 296.

37 A. Fadecka, Stowotwórstwo czasownika w gwarze, Łódź 2010, s. 58.

38 K. Dejna, Stownictwo ludowe z terenów województw kieleckiego i łódzkiego, „Rozprawy Komisji Językowej Łódzkiego Towarzystwa Naukowego", t. 29, 1974-1985, s. 214.

39 A. Fadecka, op. cit, s. 64.

40 M. Szymczak, op. cit., t. 6, s. 1037.

41 A. Fadecka, op. cit, s. 64. 
zakończenie czynności. Wiele struktur finitywnych ma charakter przenośny w stosunku do znaczenia podstawowego, np: nagnać 1. 'popędzić, nagonić co lub kogo do określonego miejsca' tymy kołatkamy nagnaty mu dzika na cel (TW), 2. 'sypnąć śniegiem' taka kurzawa sie robi, wjater tyle śniegu nagna, zaspy usypje (TW), 3. 'podnieść cenę' jak ktoś kce byle có sprzeda to faktorujo mu, nagnajo ${ }^{42}$; 4. 'namówić, przymusić do czego' có za dziecko, biyda go nagnać do ksionzek ${ }^{43}$; ululać się 1. 'o dziecku: zasnacé' lulało sie dzieckof kołysce, dotont śe kołysało, aż sie ululało (TW), 2. 'ubrać się ciepło' ululom śa f kożuch, to ja nie zmarzna, 3. 'upić się' ululat śa jak ńeboskie stworzanie ${ }^{44}$; zamotać 1. 'o niciach: poplątać' jak te pasma źle zamotała, splontała, to późníj dojś ni mogła do ładu z nimy (TW), 2. 'zadać kołtun - rzucić urok' Jakaś baba muśała zamotać tego czlowieka, że wnetki pomer ${ }^{45}$; zaperzyć sie 1. 'zarosnąć perzem' nie można dopuścić, żeby sie pole zaperzyło, bo sie nic nie urodzi, pyrz to jes tokropny (TW), 2. 'dostać biegunki (o pszczołach)' na wiesne sie pcoly lubia zapyrzić, kie ni moga sie dlugto tobleciećt6.

Wyrazistą kategorię semantyczną, choć nie tak liczną jak poprzednie, tworzą konstrukcje werbalne o funkcji ilościowej, określające stopień intensyfikacji akcji. Podobnie jak struktury przestrzenne, powoływane są często na zasadzie przeciwieństwa znaczeń, które możemy odczytać z kontekstu poprzez zastosowanie przysłówków określających poziom natężenia danego procesu (troche, nieco, bardzo, za bardzo, czasem, mocno itp.), np.: przechtodzić się 1. 'mała intensywność akcji' te wiśnie do chłodni ocstawiajom, żeby sie troche przechłodzity (TW), 2. 'duża intensywność akcji - przemarznąc' może sie pani przechtodziła za bardzo ji tak pokichuje; jag za bardzo sie przechłodzi, to można dostać drgawków z zimna (TW); przepaść 1. 'nakarmić od czasu do czasu' zimia sie ugorzy, trawa na nij rośnie, nie obrabja sie tylko czasym krowamy przepasie (TW), 2. 'zjeść za dużo' bydło możno mocno przepaś $^{47}$; przepaść bydto ${ }^{48}$.

O ile niektóre przedrostkowe struktury polisemiczne można przyporządkować do jednej, konkretnej kategorii semantycznej, o tyle istnieje jeszcze szereg odpowiedników wieloznacznych, które, choć utworzone od tej samej podstawy, należą do różnych kategorii znaczeniowych. Zmiany wartości kategorialnych powstają najczęściej w wyniku przesunięć semantycznych. Na przykład prefiks do- w czasowniku dobrać pełni w gwarach aż 3 różne

\footnotetext{
42 J. Kąś, Stownik gwary orawskiej, Kraków 2011, t. 1, s. 629.

43 Ibidem, s. 629.

44 B. Sychta, op. cit., t. 2, s. 111.

45 Ibidem, t. 3, s. 133.

46 M. Kucała, Porównawczy stownik trzech wsi małopolskich, Wrocław 1957, s. 128.

47 A. Fadecka, op. cit., s. 82.

48 P. Bąk, Gwara okolic Kramska w powiecie konińskim. (Zarys fonetyki i słowotwórstwa), Wrocław-Warszawa-Kraków 1968, s. 129.
} 
funkcje: addytywną, wskazującą na czynność dodatkową: zińć przyjechot, jeszcze jednygo do tych królików se dobrat (TW), rezultatywną, informującą o osiągnięciu celu, zakończeniu akcji: dobrot kónia na jarmarku podłók swojigo kaśtana ${ }^{49}$ oraz intensyfikującą, oznaczającą 'zwiększenie tempa zrobienia czegoś' mielimy takieg saternusa kónia, to tyn kie dobrat choćkie, toś go nie udzierzat, a ino trapa ${ }^{50}$. Także przedrostek $\boldsymbol{n a}$ - w derywacie nastarczyć wnosi zarówno znaczenie ilościowe: człowiek na to wszysko ni może nastarczyć piniążków, stale tylko rachunki, leki, wyngiel kupić (TW), jak i przestrzenne: leciol tak, że ni mogłam nastarczyć za niem ${ }^{51}$. Podobnie prefiks przy-w formacji przysadzić oznacza czynność dodatkową: stare drzewa powyżynaty, a młode drzewka przysadzity (TW), wnosi wartość przestrzenną, czyli zbliżenie do lokalizatora 'o kosie: przygiąc w stronę kosiska': jag za bardzo ocsadziły kose ot kosiska to sie nie nadawała do koszynia, to musiały jom bardzij przysadzić, żeby lepij podbierała (TW), jak również informuje o rezultacie czynności oznaczającej dostosowanie do sytuacji: 'przeznaczyć cielę na chowanie, nie na sprzedaż' ja kce przisadzić, a łociec kca sprzedać (cielę) $)^{52}$. Konsekwencją rozbudowanej polisemii werbalnej jest brak wyrazistości funkcyjnej formantów, a co się z tym wiąże, także przejrzystości kategorii semantycznych.

Analiza materiału gwarowego pokazuje, że czasownikowe odpowiedniki (słowotwórczo-leksykalne) o charakterze polisemicznym derywowane są głównie za pomocą przedrostków, które ograniczają rolę sufiksów ${ }^{53}$ do minimum. Odnotowano zaledwie kilka denominalnych czasowników o charakterze wieloznacznym (najczęściej w znaczeniach przenośnych), derywowanych za pomocą formantów paradygmatycznych: -ać, np: bzdurać 'dąsać się, gniewać' ${ }^{54}$ (znaczenie podstawowe: opowiadać bzdury), -ić/-yć, np.: gnoić 'niszczyć' 55 (znaczenie podstawowe: nawozić pole gnojem), skromnić 'sprzątać'56 (znaczenie podstawowe: żyć skromnie), -ować, np.: beczkować 'mieć wzdęcia $^{57}$ (znaczenie podstawowe: zamykać w beczce). Derywaty te mają najczęściej charakter kauzatywny (sprawczy), ponieważ informują o działaniu świadomego agensa na obiekt w określonym celu, stanowy, gdyż wyrażają stan subiektu bądź czynnościowy, ze względu na wykonywanie czynności przez

\footnotetext{
49 J. Kąś, op. cit., t. 1, s. 108.

Ibidem, s. 165.

A. Fadecka, op. cit., s. 92.

M. Kucała, op. cit., s. 125.

W nowszych opracowaniach sufiksację określa się jako derywację paradygmatyczną, a między przyrostkiem słowotwórczym a formantem paradygmatycznym stawia się znak równości (por. A. Nagórko, Zarys gramatyki polskiej, Warszawa 2003, s. 195).

54 B. Wyderka (red.), Słownik gwar śląkich, Opole 2000-2016, t. 3, s. 153.

55 J. Kąś, op. cit., t. 1, s. 207.

56 B. Sychta, op. cit., t. 3, s. 70.

57 B. Wyderka (red.), op. cit., t. 2, s. 3.
} 
agensa za pomocą czegoś, co wyraża rdzeń. Ograniczona funkcja przyrostków paradygmatycznych $\mathrm{w}$ derywowaniu czasowników polisemantycznych wynika zapewne z tego, że to głównie prefiksy narzucają podstawom słowotwórczym zbieżne wartości i łączą je w określone klasy semantyczne.

\section{PODSUMOWANIE}

W bogatej literaturze lingwistycznej istnieje wiele poglądów dotyczących definiowania zarówno samego zjawiska polisemii, jak i zakresu poszczególnych kategorii słowotwórczych. Jeszcze większy problem stanowi desygnowanie właściwego pojęcia, które w należyty sposób określałoby tożsame pod względem budowy słowotwórczej, lecz różne znaczeniowo leksemy gwarowe. I choć znalezienie „złotego środka” jest w istocie trudne, powinnością każdego językoznawcy powinno stać się dążenie do wskazywania sił stabilizujących ten wielowymiarowy układ.

Próbując pokazać zależność pomiędzy werbalnymi konstrukcjami o charakterze polisemicznym a ich funkcyjnością kategorialną w gwarach polskich, ustalono, że wykładnikami znaczeń kategorialnych są w głównej mierze przedrostki. Istnieje dość duża liczba czasownikowych odpowiedników o charakterze wieloznacznym, które można ująć w karby ogólnych kategorii semantycznych o wartościach: przestrzennych, czasowych oraz ilościowych. Jednak przywoływane $\mathrm{w}$ tekście struktury, w obrębie tych podstawowych kategorii, nabierają konkretnych wartości semantycznych, będących następstwem zjawiska enantiosemii, czyli przeciwieństwa znaczeń (np. przestrzenne formacje ablatywne i adlatywne, derywaty o małej i dużej intensywności akcji) oraz przesunięć semantycznych. Dlatego też istnieje wiele derywatów polisemicznych (w obrębie jednej gwary), jak i międzysystemowych zbieżności semantycznych różnogwarowych, które nie poddają się prostej klasyfikacji słowotwórczej, ze względu na znaczny rozdźwięk znaczeniowy i wielofunkcyjność przedrostków. Jak zauważyła A. Janowska, „tworzenie dużej liczby konstrukcji jednostkowych bądź nieregularnych [...] sprzyja zamazywaniu wyrazistości kategorii słowotwórczych" ${ }^{58}$, stąd obraz derywacji czasownikowej nigdy nie będzie do końca klarowny. Niemniej jednak, nawiązując raz jeszcze do myśli B. Walczaka na temat nowych i oryginalnych jakości językowych rodzących się na pograniczach ${ }^{59}$, należy zauważyć, że nie poznalibyśmy wielu wyjątkowych znaczeń słów i procesów ich powoływania, izolując słowotwórstwo od semantyki oraz prowadząc badania tylko w zakresie jednej gwary i nie odnosząc się do pozostałych systemów gwarowych.

58 A. Janowska, Polisemia jako czynnik..., s. 207.

59 B. Walczak, op. cit., s. 19. 


\section{ROZWIĄZANIE SKRÓTÓW}

EJP - Encyklopedia języka polskiego. 1999. Red. Urbańczyk S. i Kucała M. Wrocław: Zakład Narodowy im. Ossolińskich, hasło: polisemia, s. 288.

SWJP - Stownik wspótczesnego języka polskiego. 2001. Red. Dunaj B. Warszawa: Przegląd Reader's Deagest t. 1, 2.

TW - gwara Turowej Woli (południowe Mazowsze - materiał z badań własnych).

\section{BIBLIOGRAFIA}

Bąk Piotr. 1968. Gwara okolic Kramska w powiecie konińskim. (Zarys fonetyki i stowotwórstwa). Wrocław-Warszawa-Kraków: Zakład Narodowy im. Ossolińskich.

Blank Andreas. 2003. Polysemy in the lexicon and in discourse. W: Polysemy. Flexible patterns of Meaning in Mind and Language. Red. Nerlich B., Todd Z., Herman V., Clarke D.D., de Gruyter M., Berlin-New York: 267-293.

Buttler Danuta. 1968. Problematyka badań nad homonimią. „Przegląd Humanistyczny” t. $3: 57-80$.

Buttler Danuta. 1991. Procesy eliminacji wieloznaczności w drugiej połowie XIX wieku. „Prace Filologiczne” t. 36: 229-235.

Czelakowska Anna. 2014. Polisemia regularna - między semantyka a kontekstem. „LingVaria” 9 nr 1 (17): 45-58.

Dejna Karol. 1974-1985. Stownictwo ludowe z terenów województw kieleckiego i łódzkiego. „Rozprawy Komisji Językowej Łódzkiego Towarzystwa Naukowego” t. 20: 189-277, t. $21: 135-290$, t. $22: 135-268$, t. $23: 147-290$, t. $24: 149-274$, t. $25: 123-$ 276, t. 26: $117-257$, t. $27: 129-281$, t. 28: 119-261, t. 29: 83-233, t. 30: 91-213, t. 31: $143-265$.

Doroszewski Witold. 1949. Język Teodora Tomasza Jeża (Zygmunta Miłkowskiego). Studium z dziejów języka polskiego XIX wieku. Warszawa: Towarzystwo Naukowe Warszawskie.

Ejsmunt-Wieczorek Izabela. 2012. O nieostrości granic słowotwórczych kategorii werbalnych w gwarach. „Rozprawy Komisji Językowej Łódzkiego Towarzystwa Naukowego" t. 58: 73-84.

Ejsmunt-Wieczorek Izabela. 2017. Polisemia werbalna w gwarach. „Rozprawy Komisji Językowej Łódzkiego Towarzystwa Naukowego" t. 64: 43-57.

Fadecka Anna. 2010. Stowotwórstwo czasownika w gwarze. Łódź: Wydawnictwo Akademii Humanistyczno-Ekonomicznej w Łodzi.

Gala Beata. 2012. Znaczenie leksykalne jako wspótwyznacznik kategorialnej funkcji derywatu. „Rozprawy Komisji Językowej Łódzkiego Towarzystwa Naukowego” t. 58: 103-109.

Gala Sławomir. 2001. Z metodyki badań pogranicza językowego (na materiale polskim). W: Język i kultura na pograniczu polsko-ukraińsko-białoruskim. Red. Czyżewski F. Lublin: Instytut Europy Srodkowo-Wschodniej: 29-39.

Gala Sławomir. Gala Beata. 2006. Słowotwórcze a leksykalne znaczenie wyrazu. W: Ze studiów nad gramatyka i leksyka języka polskiego i ukraińskiego. Red. Czyżewski F., Gala S. Lublin: Wydawnictwo UMCS: 3-19. 
Gala Sławomir. 2010. Glosa do zagadnienia homonimii/polisemii w stowotwórstwie gwarowym. „Rozprawy Komisji Językowej Łódzkiego Towarzystwa Naukowego” t. 55: 81-88.

Górnowicz Hubert. 1967, 1973-1974. Dialekt malborski t. 1-2. Gdańsk: Gdańskie Towarzystwo Naukowe.

Grodziński Edward. 1969. O pojęciu wieloznaczności „łańcuchowej”. „Poradnik Językowy" t. 5: 258-265.

Grodziński Edward. 1972. Wieloznaczność a homonimia. „Poradnik Językowy” t. 10: $585-592$.

Grzegorczykowa Renata. 1966. O tak zwanych homonimach słowotwórczych. „Poradnik Językowy" t. 6: 244-249.

Honowska Maria. 1979. Ewolucja metod polskiego słowotwórstwa synchronicznego ( $w$ dziesięcioleciu 1967-1977). Wrocław: Zakład Narodowy im. Ossolińskich - Wydawnictwo Polskiej Akademii Nauk.

Janowska Aleksandra, Pastuchowa Magdalena. 2005. Stowotwórstwo czasowników staropolskich. Stan i tendencje rozwojowe. Katowice: Wydawnictwo Universitas.

Janowska Aleksandra. 2007a. O roli analogii w stowotwórstwie (na przykładzie czasowników staropolskich). „LingVaria” 2 (4): 115-120.

Janowska Aleksandra. 2007b. Polisemia staropolskich czasowników. Źródła, swoistość, konsekwencje. Katowice: Wydawnictwo Uniwersytetu Śląskiego.

Janowska Aleksandra. 2012. Polisemia jako czynnik przemian w polskich czasownikach prefiksalnych. W: Stowotwórstwo słowiańskie: system i tekst. Red. Sierociuk J. Poznań: Prace Komisji Słowotwórczej przy Międzynarodowym Komitecie Slawistów t. 13: 203-210.

Jaros Irena. 2009. Nazwy środków czynności w gwarach łęczycko-sieradzkich. Studium słowotwórczo-leksykalne. Łódź: Wydawnictwo UŁ.

Jochym-Kuliszkowa Lucyna. 1986. Uwagi o homonimii i polisemii leksykalnej w formacjach słowotwórczych. W: Problemy semantyki leksykalnej. Red. Blicharski M. Katowice: Prace Naukowe Uniwersytetu Śląskiego: 7-16.

Kąś Józef. 2011. Słownik gwary orawskiej t. 1-2. Kraków: Księgarnia Akademicka.

Kleszczowa Krystyna. 2000. Trwałość i zmienność w systemie słowotwórczym. W: Studia historycznojęzykowe III. Red. Rymut K., Rzepka W.R. Kraków: 115-122.

Kleszczowa Krystyna. 2007. Na straży niezmienności modeli słowotwórczych, „Biuletyn Polskiego Towarzystwa Językoznawczego" t. 63: 115-124.

Kucała Marian. 1957. Porównawczy słownik trzech wsi małopolskich. Wrocław: Zakład im. Ossolińskich - Wydawnictwo Polskiej Akademii Nauk.

Kucała Marian. 1994. Wieloznaczność wyrazów w staropolszczyźnie a we wspótczesnym języku. W: Studia historycznojęzykowe I. Red. Kucała M., Krążyńska Z. Kraków: $51-58$.

Kurdyła Tomasz. 2012. Kilka uwag o kategoryzacji słowotwórczej w języku współczesnej wsi na tle polszczyzny ogólnej. „Rozprawy Komisji Językowej Łódzkiego Towarzystwa Naukowego" t. 64: 189-199.

Majewska Małgorzata. 2001. O tak zwanych prawdziwych homonimach słowotwórczych. „Prace Filologiczne” t. 46: 417-424.

Majewska Małgorzata. 2006. Rzeczownikowe homonimy heterogeniczne: analiza synchroniczna i diachroniczna. Kraków: Wydawnictwo Lexis.

Marciniak-Firadza Renata. 2014. Zagadnienie polisemii rzeczownikowych derywatów gwarowych o charakterze czynnościowym. W: Bogactwo wspótczesnej polszczyzny. Red. Żmigrodzki P., Przęczek-Kisielak S. Kraków: Towarzystwo Miłośników Języka Polskiego: 427-437. 
Nagórko Alicja. 2003. Zarys gramatyki polskiej. Warszawa: Wydawnictwo Naukowe PWN.

Osowski Błażej. 2019. Wariantywność leksykalno-semantyczna języka wielkopolskich inwentarzy z drugiej połowy XVIII wieku. Studia z dialektologii historycznej. Poznań: Wydawnictwo Poznańskiego Towarzystwa Przyjaciół Nauk.

Pelcowa Halina. 2003. Synonimia i wieloznaczność w słowniku gwarowym. W: Gwary dziś 2. Regionalne stowniki $i$ atlasy gwarowe. Red. Sierociuk J. Poznań: Wydawnictwo Poznańskiego Towarzystwa Przyjaciół Nauk: 203-261.

Puzynina Jadwiga. 1962. Uwagi o układzie kategorialnym słowotwórstwa. „Poradnik Językowy" z. 1: 34-40.

Raszewska-Klimas Agnieszka. 2018. Wieloznaczność nazwisk Polaków. Łódź: Łódzkie Wydawnictwo Naukowe.

Sierociuk Jerzy. 2007. Problemy ustalania repertuaru kategorii słowotwórczych $w$ dialektach polskich. W: Sprachliche Kategorien und die slawische Wortbildung. Red. von Burkhardt H., Nagórko A., Verlag G.O. Hildesheim-Zürich-New York: 447-459.

Skarżyński Mirosław. 1999. Powstanie i rozwój polskiego słowotwórstwa opisowego. Kraków: Towarzystwo Autorów i Wydawców Prac Naukowych „Universitas”.

Sychta Bernard. 1980, 1985. Stownictwo kociewskie na tle kultury ludowej t. 1-3. Wrocław-Warszawa-Kraków-Gdańsk: Ossolineum.

Szymczak Mieczysław. 1962-1973. Stownik gwary Domaniewka w powiecie tęczyckim t. 1-8. Wrocław-Warszawa-Kraków: Zakład Narodowy im. Ossolińskich - Wyd. PAN.

Śmiech Witold. 1986. Derywacja prefiksalna czasowników polskich. Wrocław-Warszawa-Kraków-Gdańsk-Lódź: Zakład Narodowy im. Ossolińskich - Wydawnictwo Polskiej Akademii Nauk.

Tokarski Jan. 1981. Derywacja semantyczna jako jedno ze źródet polisemii wyrazowej. W: Pojęcie derywacji w lingwistyce. Red. Bartmiński J. Lublin: Wydawnictwo UMCS: 91-105.

Walczak Bogdan. 2001. Bug nie musi dzielić. W: Język i kultura na pograniczu polsko-ukraińsko-białoruskim. Red. Czyżewski F. Lublin: Instytut Europy Środkowo-Wschodniej: 13-19.

Witkowska-Gutkowska Maria. 1999. Staropolskie prefiksalne dublety czasownikowe i ich wspótczesne odpowiedniki. Łódź: Wydawnictwo Uniwersytetu Łódzkiego.

Wojan Katarzyna. 2010. Wstęp do badań wieloznaczności leksemów w ujęciu kontrastywnym. Gdańsk: Wydawnictwo Uniwersytetu Gdańskiego.

Wróbel Henryk. 1998. Czasownik. W: Gramatyka wspótczesnego języka polskiego. Morfologia. Red. Grzegorczykowa R., Laskowski R., Wróbel H. Warszawa: Wydawnictwo Naukowe PWN: 536-583.

Wróblewski Janusz. 1980. Polisemia (wieloznaczność) i homonimia-problemy, postulaty. W: Język, teoria - dydaktyka. Materiały IV konferencji Młodych JęzykoznawcówDydaktyków. Opole, 20-21 maja 1979. Red. Tokarski J. Kielce: 136-151.

Wyderka Bogusław. 2000-2016. Słownik gwar śląskich t. 1-16.Opole: Państwowy Instytut Naukowy - Instytut Śląski w Opolu. 


\title{
ON WORD-LEXICAL BORDERLAND \\ OF VERBAL AMBIGUOUS STRUCTURES IN POLISH DIALECTS
}

Summary. This is another article in the series devoted to the unexplored phenomenon of verbal polysemy in Polish dialects. Starting from the word-lexical borderline issue, the article deals with the problem of categorical functions of formants forming formally identical verbal constructions, which include, as a result of semantic shifts, imply doublets and poly-semantic strings. The subject is illustrated by examples from the field exploration of the Lesser Poland-Masovian borderland and from available published sources containing dialectal documentation.

Key words: dialect, wordbuilding, semantics, borderland, verb, polisemy, word-building category

\section{ПРО СЛОВОТВІРНО-ЛЕКСИЧНЕ ПОГРАНИЧЧЯ ВЕРБАЛЬНИХ ПОЛІСЕМАНТИЧНИХ СТРУКТУР У ПОЛЬСЬКИХ ГОВІРКАХ}

\begin{abstract}
Анотація. Це чергова стаття, присвячена питанню вербальної полісемії в польських говірках, яке досі не досліджувалось. Зважаючи на питання словотвірно-лексичного пограниччя, у статті зроблено спробу визначення категоріальних функцій формантів, які уворюють формально тотожні дієслівні конструкції, що внаслідок зміщення значень імплікують дублети і полісемантичні ряди. Питання проілюстровано прикладами, записаними під час польових досліджень малопольсько-мазовецького пограниччя, а такох доступними публікованими джерелами, що містять діалектну документацію.
\end{abstract}

Ключові слова: говірка, словотвір, семантика, пограниччя, дієслово, полісемія, словотвірна категорія 